\title{
Organic and Low-Input Dairy Farming: Avenues to Enhance Sustainability and Competitiveness
} in the EU

\author{
Élevage laitier biologique et faible en intrants : Pistes pour renforcer la \\ durabilité et la compétitivité dans I'Union européenne \\ Bio- und Low-input Milchwirtschaft: Möglichkeiten zur Verbesserung \\ von Nachhaltigkeit und Wettbewerbsfähigkeit in der EU
}

\section{Nigel Scollan, Susanne Padel, Niels Halberg, John Hermansen, Pip Nicholas, Marketta Rinne, Raffaele Zanoli, Werner Zollitsch and Ludwig Lauwers}

\section{Alternatives to intensive dairy production}

Since the abolition of milk quotas in Europe in 2015, a public and scientific debate is on-going as to whether dairy development would be more sustainable and competitive if it followed an input intensification pathway or relied more on integrated management of locally available natural resources. Jansik and Irz (2015) predicted a post-quota era of highly productive and more regionally differentiated development for dairying in Europe. Donnellan et al. (2009), however, warned of instability due to inadequate remuneration of the farmer's own labour and capital inputs. Intensive dairying, driven by land and labour saving technologies and realised through an increased use of external inputs, has negative environmental impacts in terms of water, soil and air pollution and damage to ecosystems. Organic and low-input (LI) dairy farming can reduce environmental harm by reducing external input use. The question then is whether low input and organic production can be financially viable in the post-quota era in which market forces exert a greater impact. The five-year (2011-16) Sustainable Organic and Low Input Dairying (SOLID) project, funded by the European Commission, tackled these issues in order to support innovation in European organic and low-input dairy farming.
SOLID involved researchers and stakeholders (mainly SMEs) in a multidisciplinary and multi-actor approach. The project objectives were to evaluate competitiveness and environmental sustainability of organic and low-input systems, to investigate ways to increase their profitability, and to disseminate knowledge to key stakeholder groups. Stakeholders were also involved in identifying research needs.

\section{$\mathbf{C}$ Les systèmes} d'élevage laitier biologiques et faibles en intrants peuvent adopter des stratégies innovantes pour améliorer leur compétitivité. $y$

Organic farming is clearly defined through European legislation (Regulation (EC) 834/2007), which provides a level playing field in terms of trade in organic products, as well as assurances for the consumer that products have been produced to a given standard. Because of a lack of clear definition for low-input dairying, SOLID proposed a differentiation of farms according to an indicator of external input use per grazing livestock unit on the farm. At the country level, the 25 per cent of farms with lowest external input use were considered as low-input farms, while the 25 per cent of farms with the highest external input use were considered as high-input farms. This pragmatic categorisation is not intended to define, but rather make it possible to analyse, the profitability of dairy farms among the various production systems across Europe and to detect withincountry differences according to external input use (see Box 1).

The economic competitiveness of organic and low-input dairying systems

In most of the 20 countries studied, low-input and high-input farms clearly represent two distinct production systems. Across the EU, low-input dairy farms are (compared to their high-input counterparts) smaller, less specialised, employ more family labour and allocate a larger share of their utilised agricultural area to forage and grassland, as well as using a lower share of maize in feed. Low-input farms clearly have lower productivity, regardless of whether milk production is expressed per animal, per utilised agricultural area or per labour unit. Capital productivity, however, is clearly lower on high-input farms. However, low-input farms have significantly lower capital investment (e.g. for buildings, livestock). 
Box 1: Building the SOLID approach to low-input farming systems differentiation

The absence of any formal definition of 'low-input' farming presents problems for analysing competitiveness using farm economic datasets, such as the EU Farm Accountancy Data Network (FADN). Using previous studies (IRENA, EEA, 2005), stakeholder consultation and testing with UK, Belgian and EU FADN datasets, an indicator of low-input conventional farming was defined as (Bijttebier et al., 2017):

$$
\frac{\sum \text { (Purchased feed for grazing livestock, fertiliser, crop protection, energy (fuel and electricity)) }}{\text { Grazing Livestock Units (GLU) }} .
$$

Input expenditure varied considerably between EU regions and Member States. SOLID stakeholders were consulted and there was a strong feeling that the low and high input cut-off values should be applied at Member State level. For each of the twenty countries studied, 25 per cent of holdings per Member State were allocated to the low-input farm group, ensuring the analysis considered all EU countries.

Nevertheless, in terms of profitability low-input farms perform relatively well. Analysis over the 2004-12 period showed that low-input farms, being less dependent on external inputs, are less vulnerable to input price shocks from outside the farm. As a consequence, their profitability tended to be less volatile.

\section{Low-input und ökologische Milchwirtschaftssyst eme können innovative} Strategien einführen um ihre Wettbewerbsfähigkeit zu verbessern.

Organic dairy farms also show different results across countries. For example, in Finland organic dairy farming structurally (in terms of farm size and organisation, see Bijttebier et al., 2017) resembles low-input systems, whereas in the UK the farms are structurally more similar to high-input farms. Organic farms have lower costs for some inputs (e.g. fertiliser) and benefit from a milk price premium, but this is not always sufficient on all farms to compensate for the higher costs for organic concentrates and for the lower productivity.

\section{Innovations to increase efficiency in organic and low- input dairying systems}

\section{Can participatory research deliver} innovation in practice? A farmer-led participatory approach was used to identify the challenges faced by European organic and low-input dairy farming. At an early stage, rapid sustainability assessments (Marchand et al., 2014) conducted on case farms showed areas of strength and weakness on each farm (see http://www.solidairy. eu/index.php/case-farms/). Key indicators were: soil management, biodiversity, landscape and heritage, water management, nutrient management, energy and carbon, food security, agricultural systems diversity, social capital, farm business resilience, and animal health and welfare. The assessments confirmed diversity in terms of size and intensity of organic and low-input dairy farms. Farm size ranged from less than 20 ha to more than 400 ha, herd sizes from 9 to 300 cows and milk yield from less than 2,500 to more than 8,000 litres/cow/year.

Eighteen participatory projects were conducted in close collaboration between farmers and researchers, covering various strategies related to feeding and forage, natural resource use, environmental and animal management. The experience showed that such a collaborative approach contributes to developing practical knowledge about sustainable organic and low-input dairying (Padel et al., 2015) (see Box 2).

\section{Efficiency increases through adapted genotypes? A key SOLID objective was to compare commonly used breeds with breeds perceived by farmers and industry actors as being 'better adapted' to specific conditions within countries and regions. Low-input production systems require a cow that is resilient i.e. can consume large quantities of forage per unit body weight, efficiently convert this forage into high value milk, become pregnant within a defined breeding season, and has a high health status. High-yielding}

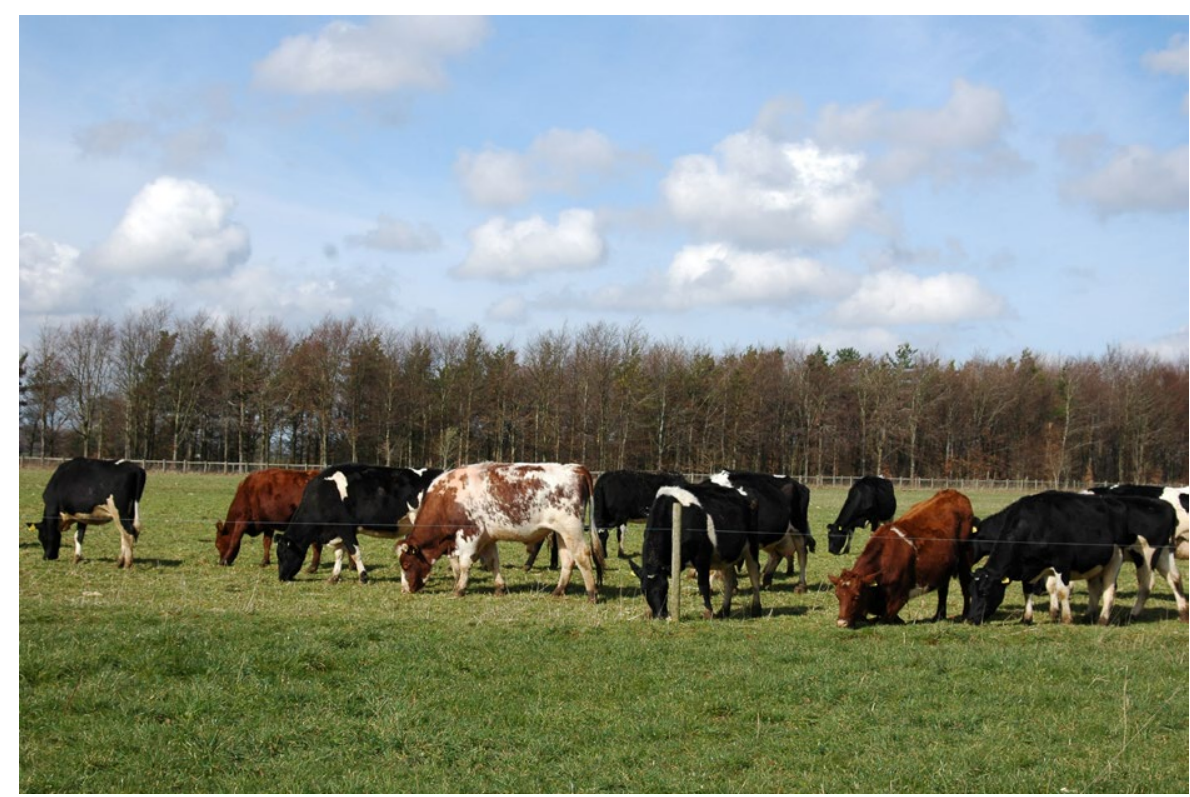

Mob grazing cattle in UK participatory case study. ( ) SOLID 2016. 
Box 2: Some examples of SOLID on-farm participatory studies

In the UK, growing a diversity of grasses (swards) was shown to be a viable alternative to conventional pastures as they can maintain both pasture and animal productivity at high levels. On-farm trials and case studies indicate that rotational, intensively stocked grazing of bio-diverse pastures can have a significant effect on the build-up of soil organic matter. In addition, multi-species pastures (several species of legumes, grasses and herbs) are sufficiently productive to serve as a viable alternative to conventional grass / clover pastures and can maintain animal productivity at high levels.

In on-farm projects in the UK and Denmark, several strategies to support animal health and welfare were developed, highlighting low use of antibiotics as an important low-input criterion. Strategies included multi-species grasslands, letting calves suckle their mothers for at least one month after calving, and establishing farmer groups to reduce use of antibiotics via health promoting strategies.

In Southern Spain, the use of silage produced from agro-industrial by-products in dairy goat feeding was an effective strategy to reduce feeding costs without compromising animal productivity. The use of irrigated sown pasture in semiintensive dairy goat production systems in Greece was a promising practice considering the high cost of feeding indoors.

Effective management is the key to success in all cases in practice.

(http://farmadvice.solidairy.eu)

dairy cows, selected under highconcentrate input conditions, do not always satisfy these criteria.

Looking for alternative cow breeds provides no obvious choice, given the diversity of organic and low-input systems throughout Europe. SOLID showed that, within well-managed herds, breeds perceived as being better adapted to low-input and organic systems did not necessarily show substantial advantages over conventional breeds. The 'adapted' breeds, however, had specific strengths (such as fewer health and metabolic disorders) that offer particular advantages in specific environments (Horn et al., 2013). The large genetic variability allows for the selection of animals for

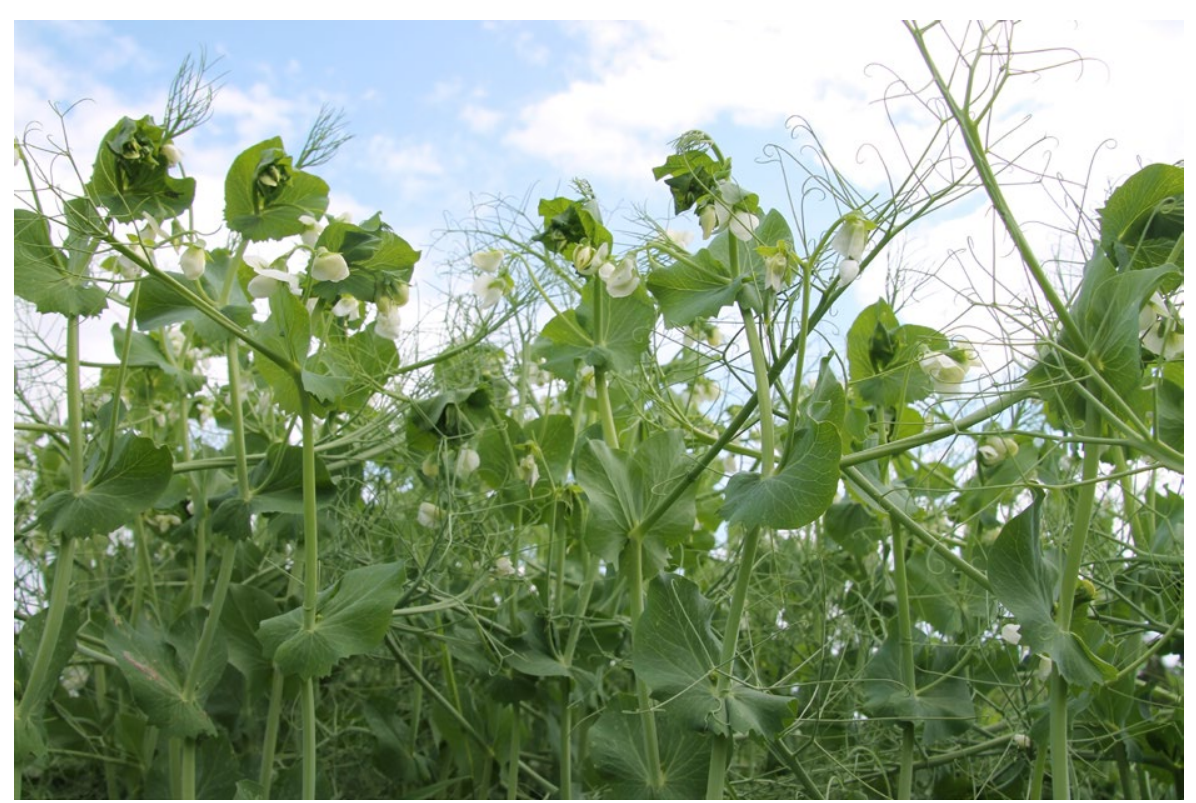

A pea crop as an example of an underutilised protein feedstuff in organic and low-input dairy production. () SOLID 2016. particular situations. A good understanding of a herd's strengths and weaknesses is the first step in defining traits that need improvement.

\section{Efficiency increases through feeding?}

In terms of energy requirements for maintenance or milk production, no significant differences were found between Holstein and 'adapted' non-Holstein cows (Dong et al., 2015a). Hence, feed systems for Holstein cows are also appropriate for other breeds. Some alternative cow breeds are lighter than Holstein cows, resulting in a lower energy requirement for maintenance. In addition, some breeds (such as Jersey crossbred cows) produce milk with a higher fat content, which will increase energy requirements for milk production.

However, dairy cows utilise predominantly forage-based diets less efficiently. Dong et al. (2015b) indicated that a $600 \mathrm{~kg}$ cow consuming a high forage rather than highconcentrate diet, needs about $0.7 \mathrm{~kg}$ more dry matter per day for maintenance. This increases even further for diets containing poor quality forages. Cows fed a high-forage diet require more time and effort to feed, ruminate and digest, which requires additional energy and feed rationing systems should be updated to reflect this.

Organic and low-input farms typically rely on farm-produced feeds, particularly grazed and conserved forages. Supply chain stakeholders are particularly interested in improved protein supply to cows and in alternatives to imported soya (Nicholas et al., 2014). Proposed solutions ranged from increasing the protein content of swards, promoting the production of grain legumes, and using industrial by-product feeds. A major challenge in considering new feed solutions is to buffer periods of feed shortages due to effects of variable weather conditions on homegrown forage. A Decision Support System was developed (Baldinger et al., 2015) to demonstrate the variability of forage production and possible reactions (https://zalf-lse. github.io/solid-dss/; Baldinger et al., 2015). 


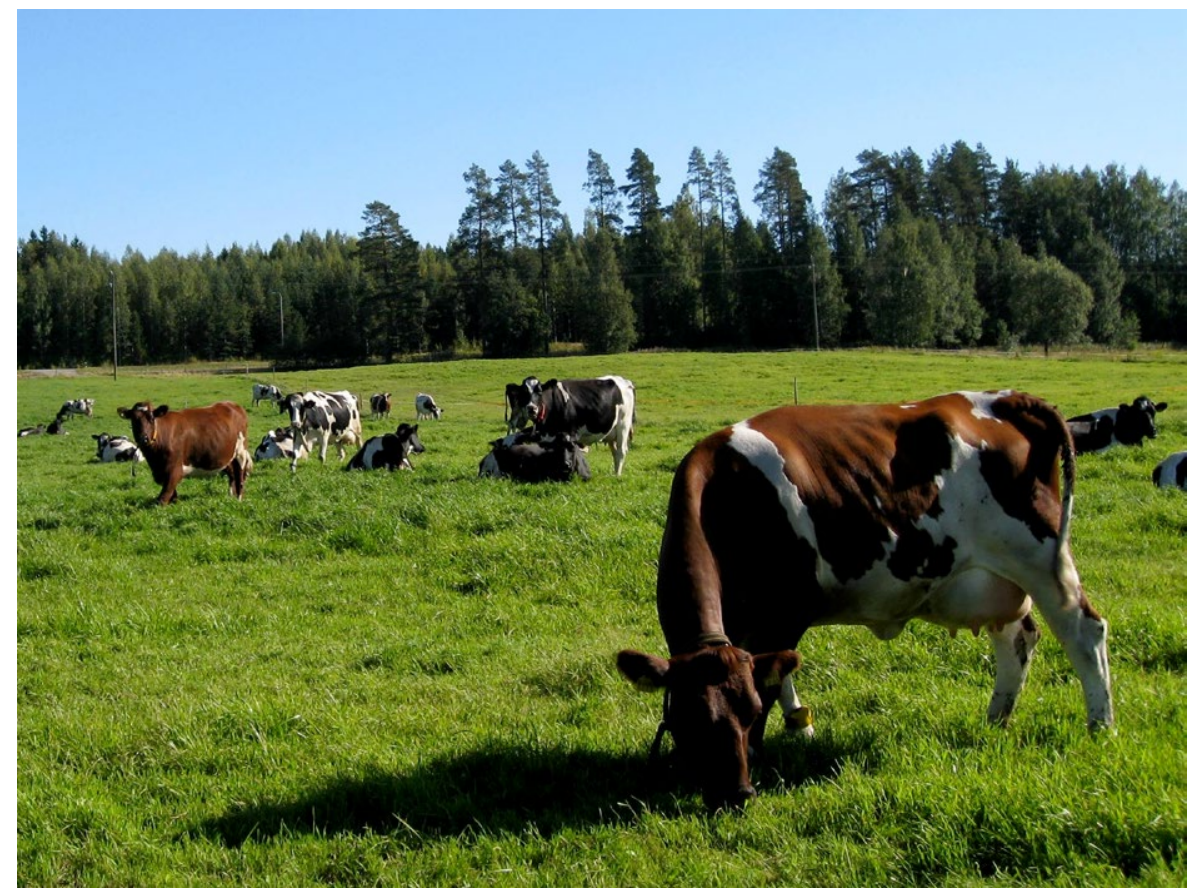

The large variability in the genetic merit of breeding animals allows for the selection of animals that are suitable for individual herds or farms. (c) SOLID 2016.

\section{The environmental performance of organic and low-input dairy systems}

Decreasing the negative environmental impact of dairy farming practices is particularly important in reducing greenhouse gas emissions and nitrogen and phosphorus losses. A major factor in assessing livestock's environmental impact concerns the area of land directly or indirectly used. Trade-offs in environmental performance are difficult to disentangle, hence also the persistent discussion on land sparing (less land used). Organic dairying typically occupies 20-50 per cent more land per $\mathrm{kg}$ of milk produced than more intensive conventional dairying, when accounting for both the directly occupied farmland and the farmland used for production of imported feed. used) and land sharing (more land
Given the objectives of on-going EU initiatives such as the Road Map for a competitive low carbon economy in 2050 and the Product Environmental Footprint, SOLID developed new methodologies to include soil carbon sequestration and biodiversity in a lifecycle approach assessment (Petersen et al., 2013). The carbon footprint of organic milk production is reduced when soil carbon sequestration is included in the assessment. Figure 1 shows the carbon footprint of milk from organic farms in three countries with or without accounting for soil carbon. Carbon sequestration is mainly due to the reliance on grassland as a feed input; and similar effects could be expected from grassland-based conventional dairy farming, whereas typically no net carbon sequestration is expected from dairy systems where annual crops are used in feed. Biodiversity was included in the lifecycle assessment through a new indicator of biodiversity damage, which compares potential loss of species of vascular plants by different farming practices with the biodiversity in comparable uncultivated land. Because of the higher proportion of grassland in the organic systems, milk from organic farms does not imply the same level of biodiversity damage as milk from conventional systems.

Figure 1: Carbon footprint of milk from individual organic dairy farms in UK, Denmark and Finland, with and without soil carbon sequestration

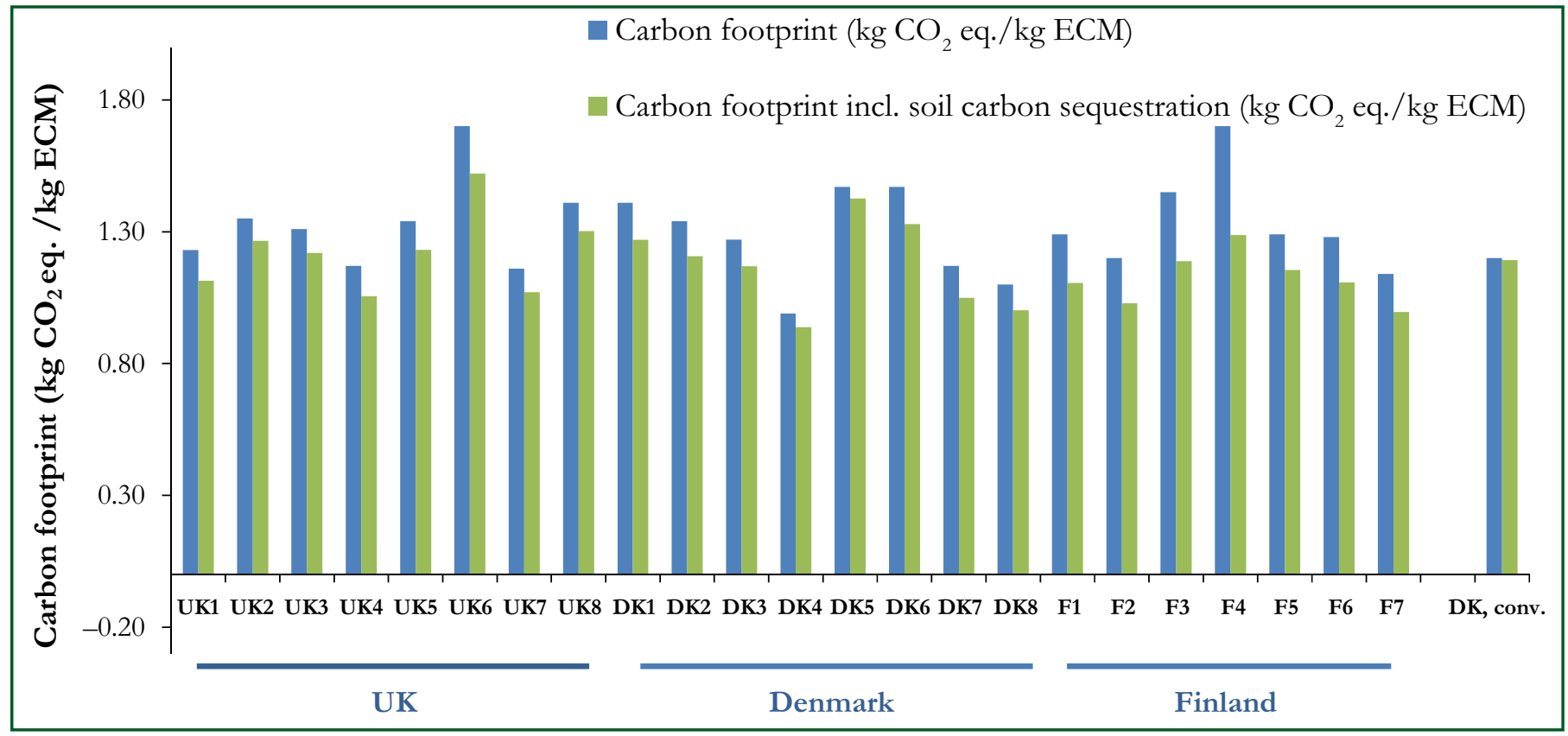

Source: http://farmadvice.solidairy.eu/wp- content/uploads/2016/05/SOLID_technical_note9_carbon.pdf 
Recommendations for policy and farm planning

SOLID research provided evidence that 'one-size-fits-all' solutions to improve competitiveness are less likely to be relevant to low-input and organic dairying. The farm systems have diverse characteristics and their starting points for improving competitiveness are country and context specific. The various SOLID modelling exercises at farm, sector and EU policy level demonstrated that designing generic strategies can be problematic, as some subsidies, taxes or other measures (e.g. from manure policy) may cause indirect effects that hamper low-input and organic strategies. Generic policies, targets or objectives are possible, but how they are delivered should be country and context specific. Organic and low-input farms need policy measures that support the development of tailor-made farm business plans and strategies based on good practice examples.
66 Low-input and organic dairy farming systems can adopt innovative farming strategies to improve competitiveness. 5

One particular avenue for improving revenues in low-input farming would be obtaining a price premium that rewards the environmental and societal benefits of the system. SOLID research, however, revealed little scope for this, apart from organic certification. Most consumers consider milk as a commodity and seem unlikely to be willing to pay more for another animal diet or better animal welfare, unless the farm is certified organic. However, the participatory processes within the SOLID project demonstrated the potential for improved competitiveness of some production strategies, such as using more home-grown proteins or making use of by-product feeds. To improve competitiveness, farm and farmer-specific strategic decisions about allocating land, labour and capital, with decisions about forage cropping, grassland management, breeds and production capacity seem necessary.

In times of increased economic pressure for dairy farming, there are opportunities for low cost and/or tailored organic practices as alternative and profitable forms of milk production. The research highlights the importance of good dairy-herd management practices, adapted to specific circumstances. To facilitate uptake of the results the SOLID partners have compiled the results, including E-learning and model tools, on a web portal targeting farmers, advisors and students: http://farmadvice.solidairy.eu/.

For more information: http://www.solidairy.eu http://farmadvice.solidairy.eu/

\section{Further Reading}

Baldinger, L., Vaillant, J., Zollitsch, W. and Rinne, M. (2015). Making a decision-support system for dairy farmers usable throughout Europe: the challenge of feed evaluation. Advances in Animal Biosciences, 6(1): 3-5.

a Bijttebier, J., Hamerlinck, J., Moakes, S., Scollan, N., Van Meensel, J. and Lauwers, L. (2017). Low-input dairy farming in Europe:

exploring a context-specific notion. Agricultural Systems, 156: 43-51.

Dong, L.F., Yan, T., Ferris, C.P. and McDowell, D.A. (2015a) Comparison of maintenance energy requirement and energetic efficiency between lactating Holstein-Friesian and other groups of dairy cows. Journal of Dairy Science, 98(2): 1136-1144.

Dong, L.F., Ferris, C.P., McDowell, D.A. and Yan, T. (2015b). Effects of diet forage proportion on maintenance energy requirement and the efficiency of metabolizable energy use for lactation by lactating dairy cows. Journal of Dairy Science, 98(12): 8846-8855.

$\square$ Donnelan, T. Hennessy, T. and Hennessy, T. (2009). Perspectives on the competitiveness of EU dairy farming. EuroChoices, 8(1): 23-29.

- Jansik, C. and Irz, X. (2015). Competitiveness makes a difference in the European dairy sector. EuroChoices, 14(3): 12-19.

- Horn, M., Steinwidder, A., Gasteiner, J., Podstatzky, L., Haiger, A. and Zollitsch, W. (2013). Suitability of different dairy cow types for an Alpine organic and low-input milk production system. Livestock Science, 153(1-3): 135-146.

- Marchand, F., Debruyne, L., Triste, L., Gerrard, C., Padel, S. and Lauwers, L. (2014). Key characteristics for tool choice in indicator-

based sustainability assessment at farm level. Ecology and Society, 19(3): 46.

- Nicholas, P.K., Mandolesi, S., Naspetti, S. and Zanoli R. (2014). Innovations in low input and organic dairy supply chains-What is acceptable in Europe? Journal of Dairy Science, 97(2): 1157-1167.

- Petersen, B.M., Knudsen, M.T., Hermansen, J.E and Halberg, N. (2013). An approach to include soil carbon changes in life cycle assessments. Journal of Cleaner Production, 52(1): 217-224.

- Padel, S., Vaarst, M. and Zaralis, K. (2015). Supporting innovation in organic agriculture: a european perspective using experience from the SOLID project. Sustainable Agriculture Research, 4(3): 32-41

Nigel Scollan, Queens University Belfast, UK. Email: Nigel.Scollan@qub.ac.uk

Susanne Padel, Organic Research Centre, UK. Email: Susanne.p@organicresearchcentre.com

Niels Halberg, International Centre for Research in Organic Food Systems, Denmark. Email: niels.halberg@icrofs.org

John Hermansen, Aarhus University, Denmark. Email:john.hermansen@agro.au.dk

Pip Nicholas, Aberystwyth University, UK. Email:pkn@aber.ac.uk

Marketta Rinne, Natural Resources Institute, Finland. Email: marketta.rinne@luke.fi

Raffaele Zanoli, Università Politecnica delle Marche, Italy. Email: zanoli@agrecon.univpm.it

Werner Zollitsch, BOKU-University of Natural Resources and Life Sciences, Austria. Email: werner.zollitsch@boku.ac.at

Ludwig Lauwers, ILVO, Belgium, Ghent University, Belgium. Email: ludwig.lauwers@ilvo.vlaanderen.be 


\section{Organic and Low-Input Dairy Farming: Avenues to Enhance Sustainability and Competitiveness in the EU}

\begin{abstract}
$\mathbf{V}_{4}$ Whether farming strategies built on continuing input intensification or relying on integrated natural resource management are more sustainable and competitive is at the core of the agricultural development debate. The five-year (2011-16) Sustainable Organic and Low Input Dairying (SOLID) project, funded by the European Commission, involved 25 partners across 10 European countries and was designed to support innovation in European organic and low-input dairy farming. Results show that such systems are very diverse, and need tailor-made farm-specific strategies and related policy measures. This article shows that low-input dairying has country-specific farm characteristics, and is potentially competitive when compared to more intensive dairying systems. Certified organic dairy farms commonly receive a price premium. Such market differentiation to attract a premium is not currently an eligible strategy for low-input systems, but cost savings on input use are possible. Both low-input and organic dairy farming systems can adopt innovative farming strategies to improve competitiveness. SOLID adopted a participatory approach for research and dissemination, by undertaking innovative science to answer practical problems. In working with farmers and other stakeholders, methodologies were developed to identify opportunities and novel strategies to enhance profitability, such as changes in breeding and feeding strategies, and provide support systems for on-farm use.
\end{abstract}

\section{Élevage laitier biologique et faible en intrants : Pistes pour renforcer la durabilité et la compéti- tivité dans l'Union euro-
péenne}

() Au cour du débat sur le développement agricole est la question de savoir quelles stratégies agricoles sont plus durables et compétitives, celles fondées sur la poursuite de l'intensification de l'utilisation d'intrants ou celles ayant recours à une gestion intégrée des ressources naturelles. Le projet quinquennal (2011-2016) sur l'élevage laitier durable, biologique et faible en intrants (SOLID), financé par la Commission européenne, a mobilisé 25 partenaires de 10 pays européens et a été conçu pour soutenir l'innovation dans l'élevage laitier européen biologique et faible en intrants. Les résultats montrent que ces systèmes d'élevage sont très divers et requièrent des stratégies et des mesures d'action publique adaptées. Cet article montre que les exploitations d'élevage laitier faible en intrants ont des caractéristiques différentes selon les pays et que ce système est potentiellement compétitif par rapport aux systèmes laitiers plus intensifs. Les exploitations laitières certifiées biologiques reçoivent généralement un supplément de prix (prime). Une telle différenciation permettant d'obtenir une prime sur les marchés n'est pas une stratégie accessible pour les systèmes faibles en intrants, mais des économies de coûts sur ces intrants sont possibles. Les systèmes d'élevage laitier biologiques et faibles en intrants peuvent tous deux adopter des stratégies innovantes pour améliorer leur compétitivité. SOLID a adopté une approche participative de recherche et de diffusion, en faisant appel à la science de manière innovante pour répondre à des problèmes pratiques. En travaillant avec les agriculteurs et d'autres parties prenantes, des méthodologies ont été élaborées pour identifier les opportunités et les nouvelles stratégies permettant d'améliorer la rentabilité, telles que les changements dans les stratégies d'élevage et d'alimentation, et fournir des systèmes de soutien sur la ferme.

\section{Bio- und Low-input Milchwirtschaft: Mögli- chkeiten zur Verbesse- rung von Nachhaltigkeit}

Die Frage, ob landwirtschaftliche
Strategien, die auf kontinuierlicher Intensivierung des Inputs beruhen oder ob Strategien, die auf ein integriertes Management natürlicher Ressourcen setzen, nachhaltiger und wettbewerbsfähiger sind, steht im Zentrum der Debatte um die landwirtschaftliche Entwicklung. Das von der Europäischen Kommission finanzierte Fünf-Jahres Projekt (2011-2016) „Sustainable Organic and Low Input Dairying” („Nachhaltige ökologische und Low-input Milchwirtschaft") (SOLID) umfasste 25 Partner in 10 europäischen Ländern und wurde konzipiert, um Innovationen in der europäischen ökologischen und Low-Input Milchwirtschaft zu unterstützen. Die Ergebnisse zeigen, dass die Systeme sehr unterschiedlich sind und maßgeschneiderte betriebsspezifische Strategien und entsprechende politische Maßnahmen erfordern. Dieser Artikel zeigt auf, dass die Low-input Milchwirtschaft länderspezifische Betriebscharakteristika aufweist und dass sie im Vergleich zu intensiveren Milchwirtschaftssystemen potenziell wettbewerbsfähig ist. Zertifizierte ÖkoMilchbetriebe erhalten generell eine Preisprämie. Solch eine Marktdifferenzierung, um an Prämien zu gelangen, ist derzeit keine geeignete Strategie für Low-input Systeme, aber Kostenersparnisse im Bereich der Betriebsmittel sind möglich. Sowohl Low-input als auch ökologische Milchwirtschaftssysteme können neue landwirtschaftliche Strategien einführen, um ihre Wettbewerbsfähigkeit zu verbessern. Neben innovativer Forschung für die Beantwortung von praktischen Fragen verwendete SOLID einen partizipativen Ansatz für die Forschung und Verbreitung der Ergebnisse. In Zusammenarbeit mit Landwirten und anderen Projektbeteiligten wurden Methoden zur Identifizierung von Möglichkeiten und neuartigen Strategien zur Verbesserung der Rentabilität erarbeitet, wie beispielsweise Änderungen im Bereich der Zucht- und Fütterungsstrategien sowie die Bereitstellung von Unterstützungssystemen für den Einsatz auf den Betrieben. 